\title{
Book Review: Cyanobacteria as Environmental Determinants of Health
}

\author{
Anabella Aguilera $^{1 *}$ and Leda Giannuzzi ${ }^{2}$ \\ 1 Instituto de Investigaciones en Biodiversidad y Biotecnología (INBIOTEC-CONICET) and Fundación para Investigaciones \\ Biológicas Aplicadas (FIBA), Mar del Plata, Argentina, ${ }^{2}$ Centro de Investigación y Desarrollo en Criotecnología de Alimentos \\ (CIDCA-CONICET), Facultad de Ciencias Exactas, Universidad Nacional de La Plata, La Plata, Argentina
}

Keywords: Argentina, cyanotoxins, cyanobacterial blooms, environmental epidemiology, risk assessment and risk management

\section{OPEN ACCESS}

Edited by:

Marius Nils Müller,

Universidade Federal de Pernambuco,

Brazil

Reviewed by:

Rosalba Alonso-Rodríguez,

Universidad Nacional Autónoma de

México, Mexico

*Correspondence:

Anabella Aguilera

anabella.aguilera@gmail.com

Specialty section: This article was submitted to

Marine Ecosystem Ecology, a section of the journal

Frontiers in Marine Science

Received: 22 May 2018

Accepted: 25 June 2018

Published: 18 July 2018

Citation:

Aguilera A and Giannuzzi L (2018)

Book Review: Cyanobacteria as Environmental Determinants of Health

Front. Mar. Sci. 5:242.

doi: 10.3389/fmars.2018.00242

\section{A Book Review on \\ Cianobacterias Como Determinantes Ambientales de la Salud}

Giannuzzi L., Petcheneshsky T.,Hansen M. (Argentina: Ministerio de Salud de laNación. Dirección Nacional de Determinantes de la Salud e Investigación), 2017, 258 Pages, ISBN: 978-950-38-0255-7.

Toxic cyanobacterial blooms represent a water quality issue worldwide which incidence and severity are predicted to increase due to climate change and eutrophication (O'Neil et al., 2012). Argentina is not an exception to this trend. Cyanobacterial proliferations have increased in the last two decades as a consequence of water quality changes due to human activities (Otaño et al., 2012; Aguilera et al., 2018). Unfortunately, Argentina lacks specific regulations concerning cyanobacteria and cyanotoxins in freshwater bodies, and information on cyanotoxins occurrence is still scant (Aguilera et al., 2018).

This book is the result of the collaborative work between Argentinean researchers and the Ministry of Health who constituted the "Working Group on Health Effects of Cyanobacteria in Water" intended to raise the awareness concerning the increased occurrence of toxigenic cyanobacteria and the threats they pose (Provision 2/2011, Secretariat for Health Relations and Research). The synergy and collaborative interactions within this group have been key steps to promote the establishment of national guidelines for cyanobacterial blooms in drinking and recreational waters.

This second edition is an expanded version that contains updates on topics already described in the first edition launched in 2011. The book contains 14 chapters written by 19 Argentinean researchers and specialists with extensive experience in Cyanobacteria, who complemented the text with own results and experiences. It begins with updated information on cyanobacterial taxonomy and ecology, including the description and photographs of harmful cyanobacteria found in Argentina. The book reviews molecular tools currently available for monitoring toxigenic cyanobacteria. This includes a brief introduction of the Polymerase chain reaction (PCR) technique and its use for cyanobacterial identification and the detection of toxigenic cyanobacterial populations or environmental samples. The application of quantitative PCR (qPCR) and DNA chips (diagnostic microarrays) are also described. 
Another important aspect of the book is management of harmful cyanobacteria and risk assessment. In this sense, it offers an overview of the factors that trigger bloom formation and the physical, chemical and biologic methods to control them. It also describes restoration measures for eutrophic water bodies and technologies used for nutrient reduction or removal. Within risk management, it presents the sequence of actions that can be used to provide a graduated response to the onset and progress of a cyanobacterial bloom. Alert Levels Framework is presented as a decision tree, therefore assisting decision making in water treatment plant operators and managers.

The book provides detailed coverage of documented acute illnesses associated with exposure to cyanobacteria and cyanotoxins in animals and humans. Additionally, it includes a chapter on the use of cyanobacteria in dietary supplements reviewing available studies about the presence of cyanotoxins in different commercially available products containing cyanobacteria.

Lastly, the last part reviews all the actions carried out by the Ministry of Health regarding the epidemiology of cyanobacteria and their toxins in Argentina. Epidemiological data are still limited in Argentina. There are few clinical data describing adverse health effects from exposure to cyanobacteria and cyanotoxins, making the clinical differential diagnosis difficult. In this sense, the Ministry initiated a framework for multidisciplinary interaction and cooperation among specialists in human, animal and environmental health. In cities strongly affected by cyanobacterial blooms, efforts were underway to train primary care personnel, veterinarians and those who work on or near cyanobacteria-impacted water bodies (e.g., lifeguards, environmental professionals) to identify cyanobacterial blooms, and collect and report animal and human signs and symptoms from exposure to cyanobacteria. The Ministry also introduced the concept of dogs as sentinels, as it is used in other countries as

\section{REFERENCES}

Aguilera, A., Haakonsson, S., Martin, M. V., Salerno, G. L., and Echenique, R. O. (2018). Bloom-forming cyanobacteria and cyanotoxins in Argentina: a growing health and environmental concern. Limnologica 69, 103-114. doi: 10.1016/j.limno.2017.10.006

Hilborn, E. D., and Beasley, V. R. (2015). One Health and Cyanobacteria in freshwater systems: animal illnesses and deaths are sentinel events for human health risks. Toxins 7, 1374-1395. doi: 10.3390/toxins7041374

O’Neil, J. M., Davis, T. W., Burford, M. A., and Gobler, C. J. (2012). The rise of harmful cyanobacteria blooms: The potential roles of eutrophication and climate change. Harmful Algae 14, 313-334. doi: 10.1016/j.hal.2011.10.027

Otaño, S., Salerno, G. L., Ruiz, M., Aguilera, A., and Echenique, R. O. (2012). “Argentina: Cyanobacteria and cyanotoxins: Identification, toxicology, the first indication of an ongoing cyanobacterial bloom (Hilborn and Beasley, 2015). The tool kit of materials (posters to raise awareness among the public, health records for the health personnel) as well as public health promotion activities and partnerships carried out by The Ministry of Health are presented in the last chapter of the book.

In sum, this handbook is an important resource for researchers, water manager professionals, and also specialists working in human or animal health in Latin America. It can be of interest to the wider resource management community assessing the health of freshwater ecosystems in the region. It also constitutes a reference book at a level and depth for advance graduate and research students who want to approach their research on toxic cyanobacteria.

Cyanobacterial blooms are an environmental public health issue that needs continuing attention at local and national level. Moreover, attention at international level must also be considered when countries have a share in river basins, as in the case of Latin America. We prospect this book will promote parallel initiatives in Latin American countries, and also encourage further interchange among researchers, water managers, and health authorities within our continent to take actions and work collaboratively. Finally, this book review constitutes a nice opportunity to present and spread the work done in Argentina regarding this environmental and health issue. Hopefully, it will promote scientific interchange with the non-Latin American community as well.

Link to download the handbook in PDF (in Spanish): http:// www.msal.gob.ar/images/stories/bes/graficos/0000000334cntCiano_2017.pdf

\section{AUTHOR CONTRIBUTIONS}

AA and LG wrote the book review and approve the manuscript.

monitoring and risk assessment" in Current Approaches to Cyanotoxin Risk Assessment, Risk Management and Regulations in Different Countries, ed I. Chorus (Berlin: Umweltbundesamt), 16-20.

Conflict of Interest Statement: The authors declare that the research was conducted in the absence of any commercial or financial relationships that could be construed as a potential conflict of interest.

Copyright (c) 2018 Aguilera and Giannuzzi. This is an open-access article distributed under the terms of the Creative Commons Attribution License (CC BY). The use, distribution or reproduction in other forums is permitted, provided the original author(s) and the copyright owner(s) are credited and that the original publication in this journal is cited, in accordance with accepted academic practice. No use, distribution or reproduction is permitted which does not comply with these terms. 